\title{
Introdução ao número especial Congresso-luso Afro- Brasileiro, Grupo de trabalho Análise de Redes Sociais
}

\author{
Marta Varanda- ICS-UL, Portugal ${ }^{1}$ \\ Eduardo Marques- USP, Brasil ${ }^{2}$ \\ Ana Cristina Martes- FGV, Brasil ${ }^{3}$
}

Este número especial em Português da Revista REDES resulta das comunicações apresentadas no "Grupo de Trabalho: Análise de Redes Sociais", do XI Congresso Luso Afro-Brasileiro de Sociologia que teve lugar em Salvador na Bahia em Agosto de 2011 Este grupo de trabalho teve diferentes objetivos em sua origem. Um deles foi impulsionar o uso da ARS na comunidade lusófona, onde é ainda insuficientemente conhecida, uma comunidade que se encontra muito dispersa e que em grande parte se desconhece entre si, dificultando a aprendizagem e a difusão do conhecimento (ver Varanda et al. neste número). Outro objetivo deste Grupo de Trabalho foi a valorização da lusofonia enquanto língua científica nos estudos de ARS: nesta área como em outras áreas científicas, a hegemonia anglófona é marcante. Em conseqüência, o estudo de temas sociais que têm que ver com as realidades sociais e culturais do mundo lusófono é minoritário, além de que grande parte dos escassos estudos existentes se baseia em modelos de análise muito influenciados por uma ênfase analítica externa às nossas realidades. Essas ausências tendem a se reproduzir no tempo, já que os estudos existentes têm necessariamente de se apoiar em bibliografia de suporte cujos temas e enfoques abordam outras realidades. Este fato pode introduzir enviesamentos nestes estudos cuja superação só é possível com a valorização da lusofonia como língua científica, objetivo alcançável através da criação de mais sinergias entre a investigação lusófona.

O interesse da comunidade científica lusófona por este grupo de trabalho foi grande, tendo sido recebidas 41 comunicações (das quais 7 de autores portugueses ou afiliados em Portugal). Era nosso interesse que neste grupo de trabalho fossem apresentados e discutidos trabalhos com um uso de ARS que conforma uma perspectiva de análise multidisciplinar envolvendo metodologias e ferramentas específicas para a investigação das conexões entre agentes de diferentes naturezas

\footnotetext{
${ }^{1}$ Para correspondência: marta.varanda@ics.ul.pt

2 Para correspondência: ecmarq@uol.com.br

3 Para correspondência: ana.martes@fgv.pt
} 
conectados por fluxos materiais e imateriais. Foram então selecionados 24 trabalhos, considerando não apenas a qualidade das contribuições, mas também à mobilização metodológica das redes. Desta seleção só 15 foram efetivamente apresentadas $^{4}$ e destas 10 foram escolhidas para este número especial, sendo só 6 consideradas para publicação.

A separação dos artigos que incorporam o uso metodológico das redes é importante para filtrar usos genéricos e metafóricos do conceito "redes" ou "redes sociais" muito em voga no período recente. Uma pesquisa no portal de periódicos Scielo (www.scielo.org), por exemplo, indica um crescimento impressionante da presença da expressão 'redes sociais' no título de artigos. Se entre 1996 e 2000 apenas 25 artigos foram publicados incluindo a expressão, no quinquênio subsequente foram 69 e entre 2006 e 2010 nada menos do que 289 artigos. No ano de 2011, apenas, 107 artigos constam da base bibliográfica, sugerindo uma verdadeira explosão na produção sobre o tema. Embora esse crescimento seja certamente muito positivo para a área, representa em grande parte a disseminação de usos metafóricos das redes visando caracterizar a fluidez da interação que caracteriza as sociedades contemporâneas. Esse tipo de uso tem levado a interpretações muito díspares sobre o que é a análise de redes sociais e sobre a sua aplicação no estudo dos fenômenos sociais, o que tem sido potencializado ainda pela confusão das chamadas redes sociais (Facebook, Linked in, etc.)

Pra além deste Grupo de Trablaho, outros eventos vocacionados para a análise de redes lusófona têm atraído um número substancial de autores, que por enquanto ainda se restringem ao Brasil e Portugal. Nos Encontros de Analistas de Redes Sociais organizados em Lisboa a participação tem vindo a crescer: em 2007 tivemos 13 comunicações apresentadas, em 2009 já 17 (4 resumos foram enviados por autores brasileiros, mas só 2 apresentaram comunicação), e este ano serão 25 comunicações (duas das quais de autores brasileiros). A Sessão Ibero-americana do Congresso Internacional de Análise de Redes Sociais (SUNBELT) na Itália em 2010, contou com a presença de 8 portugueses e 3 brasileiros. Apesar da adesão a estes vários eventos denota-se que as barreiras geográficas têm um forte impacto nos níveis de participação, sendo as deslocações transatlânticas um fator inibidor.

Outros indicadores da expansão desta perspectiva teórico-metodológica, são, por exemplo: a) a evolução das publicações (identificada em Varanda et al.); b) o fato de alguns autores deste número especial (e também dos revisores convocados) não constarem da base de dados de artigos de revistas analisada em Varanda et

\footnotetext{
${ }^{4}$ A grande maioria de autores portugueses acabou por não se deslocar a Salvador devido a restrições financeiras nas missões científicas.
} 
al, por constituírem um conjunto de autores, e potenciais autores, a iniciar o seu percurso enquanto analistas de redes; c) a dinâmica de crescimento do corpo de revisores da Revista Redes, que entre 2006-2009 eram só 2 e a partir de 2010 passaram a ser 21 (dos quais só 4 são portugueses).

Devemos, no entanto, reconhecer que para a consolidação desta especialidade científica no mundo lusófono, importantes saltos qualitativos- teóricos, metodológicos e analíticos - terão que ser dados, juntamente com uma maior concretização - nomeadamente através da publicação a nível internacional-, para além do seu alargamento a outros países lusófonos, que tanto enriqueceria o conhecimento científico sociológico global. Por exemplo, a presença lusófona na Revista REDES é ainda pálida: ao longo dos 21 números da revista REDES foram publicados 186 artigos, e só 10 deles de autores portugueses ou brasileiros (embora dois artigos tenham sido publicados em castelhano). Desde 2006 foram submetidos outros 25 artigos de naturais de países de língua portuguesa, mas que não foram selecionados para publicação De notar também que $01^{0}$ artigo em Português de autoria de Breno Fontes e Klaus Eichner foi publicado só em 2004, no Volume 7.

As temáticas abordadas pelos autores lusófonos têm-se centrado nas questões relacionadas com pobreza e participação/cidadania/associativismo/sociedade civil por um lado e conhecimento/ciência e inovação/empreendedorismo por outro. Neste número especial continua-se de certa forma esta tradição, mas novos temas são incorporados. Na temática pobreza temos os artigos de Marques et al., abordando a questão do associativismo está o artigo de Zanata Jr. e Silva, e depois as questões relacionadas com a ciência são tratadas por Rossoni e Guarido Filho, e Varanda et al. Outros temas que surgem, são as questões de cognição e identidade social por Kirschbaum, empregabilidade (também ligada à temática da pobreza) por Guimarães et al. e um artigo com uma propensão fundamentalmente metodológica de Reinert e Maciel. Os artigos de Marques e Zanata jr e Silva corroboram a tendência para homofilia, que dificulta o acesso a recursos dos estratos sociais mais baixos e os torna "invisíveis" aos olhos dos estratos sociais mais altos (o inferior está ausente, não é identificado nem referido). Demonstra-se aqui como o recurso à ARS é útil para compreender as forças que impelem à perpetuação da pobreza. No caso concreto da obtenção de trabalho Guimarães et al. demonstram como atributos e relações com propensão para a homofilia se articulam em exemplos de configuração de percursos laborais conducente à (re)produção da vulnerabilidade ocupacional. A tendência para a homofilia é ainda tratada por Rossoni e Guarido Filho, no contexto dos conselhos editoriais de revistas, em que se identifica uma 
partilha maior de conselheiros entre as revistas com qualificação semelhante, e por Varanda et al. na caracterização dos analistas de redes lusófonos e o seu apego por relações de colaboração, aconselhamento e coautoria com os mais próximos geograficamente (e socialmente/emocionalmente). Em ambos os artigos, embora de forma diferente, se chama a atenção para a componente social (e também simbólica) na construção da ciência e dos obstáculos que se vão interpondo à inovação no campo da ciência. O artigo de Kirschbaum sobre o rap como movimento cultural, de expressão de identidade de estratos populacionais segregados, permite vislumbrar um espaço de libertação do "cerco" exercido pela homofilia.

Dois dos artigos têm preocupações fortemente metodológicas: Kirschbaum propõe uma metodologia que pode simultaneamente identificar a "topologia" relacional de um campo, e preservar as lógicas locais na explicação da emergência dessa topologia. Essa explicação tem a ver com o fato de que a forma como um determinado grupo se vê no espaço social pode não corresponder à forma como os outros o vêm, o que pode ser vivenciado como um estigma. Mas por outro lado, isso pode evitar o tratamento reificado das fronteiras identitárias, e tornar mais aceitáveis as transgressões. O contributo de Reinert e Maciel centra-se na aplicação da MRQAP (Multiple Regression Quadratic Assignment Procedure), técnica também utilizada por Kirschbaum, e na ilustração da sua utilização aplicada a um caso empírico. É um artigo com uma forte vertente didática que pretende enriquecer o panorama metodológico da ARS na lusofonia

Em conclusão, sendo este número especial em português não uma amostra mas uma pequena mostra do cada vez mais vasto trabalho desenvolvido pelos Analistas de redes lusófonos, serve no entanto de exemplo da sua crescente qualidade cientifica e metodológica. Este número inclui alguns dos autores lusófonos mais citados pelos analistas de redes como Charles Kirschbaum, Eduardo Marques e Luciano Rossoni, inclui temáticas que despertam grande interesse junto da comunidade lusófona, e revela sofisticação teórica, metodológica e analítica que esperamos sirva de referência e motivação para os novos autores. 